\section{Gambaran Karakteristik Fatigue Pasien Post Stroke}

Jurnal Keperawatan dan Pemikiran IImiah Noor, M.A. (2018). Gambaran Karakteristik fatigue pasien post stroke. Nurscope.Jurnal Keperawatan Pemikiran IImiah.

4 (7). 55-60

\author{
Mohammad Arifin Noor ${ }^{1}$ \\ Fakultas IImu Keperawatan, Universitas Islam Sultan Agung Semarang
}

\begin{abstract}
Abstrak
Pendahuluan: Fatigue pada pasien stroke dapat terjadi selama fase akut ( 2 minggu) atau dalam waktu yang lama setelah serangan serangan. Penelitian ini bertujua untuk mengetahui gambaran karakteristik fatigue pasien post stroke. Metodologi deskriptif analitik dengan desain cross sectional, 22 orang (sampel) yang didapat dengan teknik purposive sampling. Sampel penelitian yaitu pasien stroke dengan fatigue. Hasil uji distribusi

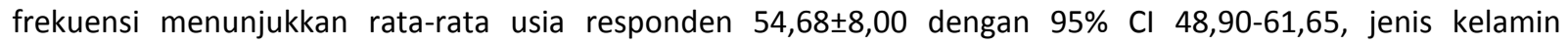
perempuan $(63,6 \%)$, gangguan emosional ringan-sedang $(59,1 \%)$, rata-rata skore fatigue post stroke $38,87 \pm 7,83$ denan $95 \% \mathrm{Cl} 35,71$ - 42,66. Diskusi : karakteristik penderita yang mengalami fatigue sangat beragam, perlu kiranya dilihat korelasi antara karakteristik dengan kejadian fatigue pasien post stroke.
\end{abstract}

Kata kunci : Fatigue, gangguan emosional, stroke

\title{
Characteristics Of Fatigue Post Stroke Patient's
}

\begin{abstract}
Introduction: Fatigue in stroke patients can occur during the acute phase ( 2 weeks) or for a long time after the attack. This study aimed to find out the description of fatigue characteristics of post stroke patients. Descriptive analytical methodology with cross sectional design, 22 people (sample) obtained by purposive sampling technique. The research sample is stroke patient with fatigue. The results of the frequency distribution test showed the average age of respondents $54.68 \pm 8.00$ with $95 \% \mathrm{Cl} 48.90-61.65$, female gender (63.6\%), mildmoderate emotional disturbance (59.1\%), average post-stroke fatigue score $38.87 \pm 7.83$ and $95 \% \mathrm{Cl} 35.71$ 42.66. Discussion: the characteristics of patients experiencing fatigue is very diverse, it is necessary to see the correlation between characteristics with the incidence of fatigue post stroke
\end{abstract}

Keywords: stroke, fatigue, emotional disturbance

Corresponding Author:

Mohammad Arifin Noor ${ }^{1}$,Fakultas Ilmu Keperawatan Universitas Islam Sultan Agung, Jalan Raya Kaligawe Km 4, Semarang, Jawa Tengah, Indonesia, Kode pos 50112; e-mail ipinnoor84@gmail.com 


\section{PENDAHULUAN}

Beberapa penyakit kronik semakin meningkat kejadiannya di seluruh dunia. Salah satunya ada di Indonesia yaitu Stroke. Stroke merupakan penyebab kematian terbanyak kedua setelah Ischemic Heart Desease, dengan usia penderita lebih dari 60 tahun (WHO, 2017). Gambaran klinis yang sering dirasakan pada pasien stroke adalah fatigue (Ponchel et al, 2015; NINDS, 2011).

Prevalensi fatigue pada kasus ini di Amerika diperkirakan 36\%-77\% (Kluger et al, 2013), sedangkan di Korea diperkirakan 23\%-75\% (Choi-Kwon \& Kim, 2011). Menurut NANDA 2015-2017 fatigue merupakan keletihan yang dirasakan secara terus-menerus dan terjadi penurunan kapasistas fisik dan maupun mental. Fatigue pada pasien post stroke dapat didefinisikan perasaan kelelahan awal yang berkembang selama aktivitas mental (emosi) dengan menunjukkan adanya kekurangan energi dan kelelahan yang berlebih, disertai keengganan melakukan aktivitas (Herdman \& Kamitsuru, 2014; ChoiKwon \& Kim, 2011).

Hasil studi dari Egerton et. al. (2015) menjelaskan prevalensi tertinggi fatigue pada pasien post stroke bisa terjadi pada bulan ke tiga setelah serangan hal ini dikaitkan dengan umur dan jenis kelamin. Studi lain kejadian fatigue dapat terjadi selama fase akut (2 minggu) pada pasien post stroke iskemik dan hal ini dikaitkan dengan depresi, aktivitas sebelum stroke dan disfungsi keluarga (Wang, et al, 2014).

Fatigue pada pasien post stroke dari beberapa studi, dijelaskan bahwa memiliki pengaruh terhadap kualitas hidup (Levine \& Greenwald, 2009), dampak fatigue sangat erat hubungannya dengan HealthRelated Quality of Live (HRQoL) dan penurunan Activity Daily Living (ADL). Selain itu kasus ini dapat dihubungkan dengan penurunan aktivitas seksual dari penderitanya (Choi-Kwon \& Kim, 2011).

Belum banyak penelitian yang membahas mengenai hal-hal terkait fatigue pasien post stroke, tetapi belum banyak penelitian terkait gambaran karakteristik fatigue post stroke. Penelitian ini bertujuan untuk mengetahui gambaran karakteristik pasien post stroke.

\section{METODE}

Desain penelitian deskriptif analitik dengan teknik cross sectional. Sebanyak (22) pasien post stroke yang menjadi sampel dipilih secara purposive sampling. Prosedur pengambilan data dilakukan selama 4 minggu di Ruang Poliklinik Saraf RSUD Tugurejo Semarang. Instrumen yang digunakan untuk mengukur fatigue yakni Fatigue Saverity Scale (FSS). Sedangkan kuesioner digunakan untuk mengukur karakteritik responden. Program komputer digunakan untuk mengolah data yang telah terkumpul. Adapun etika pengambilan data memegang prinsip self determinant privacy, anonimity, confidentiality confidentiality, dan justice. Analisis pada variabel-variabel di dalam penelitian ini dilakukan secara univariat.

\section{HASIL}

Terdapat 4 karakteristik responden yang ditampilkan, ke 4 karakteristik tersebut antaralain usia, jenis kelamin, gangguan emosional, fatigue. Rerata umur responden adalah 55,25 $(95 \% \mathrm{Cl})$ dengan standar deviasi 9,48 . Jenis kelamin dalam penelitian ini sebagian besar perempuan $(63,6 \%)$, sedangkan untuk 
gangguan emotional ringan-sedang $(59,1 \%)$, rata-rata skor fatigue 38.87 (95\% Cl) dengan standar deviasi 7,83.

\section{PEMBAHASAN}

Rata-rata responden dalam penelitian ini termasuk ke dalam klasifikasi lansia tengah dengan rentang umur 45-65 tahun. Meningkatnya usia merupakan faktor resiko utama pada kejadian stroke. Stroke bisa terjadi pada semua umur, akan tetapi $25 \%$ angka dari kejadian penyakit stroke, terjadi pada umur di bawah 65 tahun (Lewis, et al, 2011). Penelitian yang dilakukan oleh Parks et. al. (2013) menyatakan bahwa frekuensi fatigue pada pasien post stroke dengan umur yang lebih muda lebih tinggi dibandingkan dengan pasien post stroke yang memiliki umur yang lebih tua. Hal ini juga sejalan dengan penelitian yang dilakukan oleh Lerdal et. al (2013) menunjukkan bahwa kejadian fatigue post stroke yang lebih tinggi akan dialami seorang individu pada umur yaitu sekitar $<60$ tahun sampai dengan umur $>75$ tahun.

Jenis Kelamin yang dominan pada penelitian ini adalah perempuan. Hal ini sesuai dengan penelitian dari (Nadarajah \& Hui, 2015) di dalam riview artikelnya menjelaskan bahwa pada pasien stroke yang mengalami fatigue ditemukan frekuensi terbanyak adalah perempuan, sejalan dengan penelitian yang dilakukan oleh Lerdal et.al. (2011) menunjukkan tingkat fatigue sedang dan fatigue berat rata-rata dialami oleh responden perempuan, berjumlah 38 responden yang mengalami fatigue sedang 22 responden (58\%) dan 16 reponden (42\%) laki-laki, sedangkan fatigue berat pada 28 responden menunjukkan 12 responden (43\%) perempuan dan 16 responden (57\%) laki-laki. Penelitian ini relevan dengan Feigin et. al. (2012) dinyatakan bahwa sebanyak 183 (30\%) dari 613 pasien 6 bulan setelah terjadinya serangan stroke iskemik yang mengalami fatigue tidak menunjukkan perbedaan dilihat dari jenis kelamin baik itu laki-laki dan perempuan (28\% pada laki-laki dan $33 \%$ pada perempuan dengan $\mathrm{p}$ value $=0,18$ ). Menurut Christensen et. al (2008) didapatkan bahwa data karakteristik dari responden yang mengalami stroke, dari 165 responden (44\% responden perempuan dan 56\% responden laki-laki).

Pendapat dari peneliti, hal ini dikarenakan pasien post stroke yang mengalami fatigue ini sering dikaitkan dengan keadaan emosional atau psikis yang tidak baik sehingga akan mengganggu keterbatasan kemampuan fisik untuk dapat beraktivitas. Hal ini relevan dengan penelitian yang menunjukkan adanya hubungan antara fatigue pada pasien post stroke terhadap penurunan kemampuan fisik dan gejala depresi (Lerdal et. al., 2011). Penelitian lain juga menjelaskan bahwa kecenderungan pada perempuan menunjukkan tingkat pemulihan yang lebih rendah dibandingkan dengan laki-laki dan juga memiliki keterbatasan fisik berupa kelemahan dan rentang gerak yang lebih lebih parah dibandingkan dengan laki-laki (Adam, 2011). kejadian keparahan stroke akan cenderung dialami oleh perempuan dengan angka kematian sebesar $24,7 \%$ dibandingkan dengan laki-laki yaitu sebesar 19,7\% (Appelros et. al, 2009).

Gangguan emotional yang sering dialami oleh pasien post stroke yang mengalami faituge adalah gangguan emotional ringan-sedang. Hal ini sesuai dengan penelitian yang dilakukan Videbeck (2008) mengatakan bahwa, gangguan emosional merupakan suatu gejala yang tidak menyenangkan, merasakan cemas, takut dan bahkan terkadang menjadikan panik akan suatu bencana yang mengancam dan tidak terelakkan yang berhubungan dengan rangsangan eksternal. Apabila seseorang tidak mengalami gangguan emosional, maka seseorang itu tidak akan menyebabkan perubahan baik 
dari persepsi, perubahan fisik maupun emosional individu itu sendiri, sebaliknya apabila seseorang mengalami gangguan emosional maka berpotensi mengganggu fisik, mental dan persepsi yang dimiliki individu tersebut. Penyebab dari gangguan emosional sangat beragam diantaranya adalah karena adanya peristiwa traumatik, konflik emosional dan gangguan kesehatan fisik.

Penelitian oleh Yager (2014) menjelaskan bahwa gangguan emosional berhubungan dengan stroke karena berkaitan mekanisme vaskuler, neurohumoral dan inflamasi yang terjadi pada stroke. Pendapat peneliti bahwa, stroke merupakan penyakit yang dialami oleh individu dan dapat menyebabkan terjadinya gangguan emosional. Pasien post stroke dapat mengalami gangguan emosional dari yang ringan, sedang sampai berat hal ini yang dapat bisa mengakibatkan terjadinya fatigue yang dialami oleh pasien post stroke. Hal ini sesuai dengan penelitian Wu (2014) yang menyatakan bahwa fatigue post stroke biasanya sering ditunjukkan dengan adanya gejala depresi, kecemasan koping yang tidak baik, kehilangan kontrol emosi dan perubahan tingkah laku.

Skore Fatigue yang terjadi pada pasien stroke cukup tinggi, hal ini sejalan dengan penelitian dari Maaijwee et. al. (2014) yang menjelaskan bahwa fatigue yang dialami oleh post stroke akan berdampak penurunan kapasitas fungsional penderita stroke misalnya aktivitas sehari-hari, menurut Onabajo dan Adamu (2014) fatigue yang terjadi pada post stroke berdampak pada kualitas hidup terkait kesehatan dari penderita stroke.

Fatigue yang terjadi pada yang terjadi pada pasien post stroke merupakan gejala multidimensional yang mencakup aspek fisik, mental dan emosional (Wu, et al. 2014). Menurut Wang et. al, 2014 pengalaman fatigue yang dirasakan sebagai tanda dan gejala atau efek dari stroke yang diderita. Karena fatigue pada pasien dengan stroke biasa dikaitkan pada adanya gangguan psikologis dan juga kerusakan pada otak (gangguan pada korteks) yang berhubungan dengan fungsi dari jembatan silang otot sebagai perputaran kontraksi dan relaksasi otot (Davis \& Walsh, 2010). Dengan mekanisme fatigue yang terjadi pada pasien stroke masih sangat mungkin untuk dapat dikembangkan intervensi yang efektif dengan target mekanisme fatigue tersebut sehingga dapat menurunkan keluhan utama penderita.

\section{SIMPULAN DAN SARAN}

Simpulan

Sebagian besar pasien stroke mengalami fatigue adanya gangguan emotional. Rata-rata umur pasien stroke sudah memasuki dewasa akhir atau lansia awal dengan perempuan yang paling banyak mengalami kejadian fatigue.

Saran

Perlu adanya peningkatan pemahaman dan perilaku bagi penderita atau pasien stroke untuk melakukan kontrol rutin tekanan darah, olahraga ringan misalnya jalan-jalan ataupun rekreasi untuk dapat mengurangi terjadinya kejadian fatigue post stroke

\section{KEPUSTAKAAN}

World Health Organization (WHO).(2017). Top 10 causes of death worldwide. Retrieved from http://www.who.int/mediacentre/factsheets/fs310/en/ 
Adam, M. (2011). Pengaruh Akupresur terhadap Kekuatan Otot dan Rentang Gerak Ekstremitas Atas pada Pasien Stroke Pasca Rawat Inap di RSUP Fatmawati Jakarta. [Tesis]. Depok : Fakultas Ilmu Keperawatan Universitas Indonesia

Appelros P1, Stegmayr B, Terént A. (2009). Sex differences in stroke epidemiology: a systematic review. Stroke. 2009 Apr;40(4):1082-90. DOI: 10.1161/STROKEAHA.108.540781

Choi-Kwon, S., \& Kim, J. S. (2011). Poststroke fatigue: An emerging, critical issue in stroke medicine. London, England: SAGE Publications. DOI:10.1111/j.1747-4949.2011.00624.x

Christensen, D., Johnsen, S. P., Watt, T., Harder, I., Kirkevold, M., \& Andersen, G. (2008). Dimensions of post-stroke fatigue: A two-year follow-up study. Cerebrovascular Diseases, 26(2), 134-141. DOI:10.1159/000139660

Davis M.P. \& Walsh D. (2010). Mechanisms of fatigue. J Support Oncol 2010;8:164-174. Retrieved from https://www.researchgate.net/publication/46168767. accessed January 15th, 2017

Egerton, T., Hokstad, A., Askim, T., Bernhardt, J., \& Indredavik, B. (2015). Prevalence of fatigue in patients 3 months after stroke and association with early motor activity: A prospective study comparing stroke patients with a matched general population cohort. BMC Neurology, 15, 181. DOI 10.1186/s12883-015-0438-6

Feigin VL, Barker-Collo S, Parag V, Hackett ML, Kerse N, Barber PA, Theadom A, Krishnamurthi $\mathrm{R}$;(2012). Prevalence and predictors of 6-month fatigue in patients with ischemic stroke: a population-based stroke incidence study in Auckland, New Zealand, 2002-2003. Auckland Regional Community Stroke Study Group. Stroke : American Heart Association. 2012 Oct;43(10):2604-9 DOI: 10.1161/STROKEAHA.112.660886

Herdman, T. H. \& Kamitsuru, S. (2014). NANDA International Nursing Diagnoses: Definitions \& Classification 2015-2017, Tenth Edition. Oxford: Wiley Blackwell

Lerdal A, Bakken LN, Rasmussen EF. (2011).Physical impairment, depressive symptoms and pre-stroke fatigue are related to fatigue in the acute phase after stroke. Disabil Rehabil. 33(4):334-342. DOI: 10.3109/09638288.2010.490867

Lerdal A, Gay CL, Lee KA (2013) Curvilinear Relationship Between Age and Post-Stroke Fatigue among Patients in the Acute Phase following First-Ever Stroke. Int J Phys Med Rehabil 1:141. DOI: 10.4172/2329-9096.1000141

Levine, J., \& Greenwald, B. D. (2009). Fatigue in parkinson disease, stroke, and traumatic brain injury. Physical Medicine \& Rehabilitation Clinics of North America, 20(2), 347-361. DOI:10.1016/j.pmr.2008.12.006 
Lewis, S.L. (2011). Medical surgical nursing: Assessment and management of clinical problems (8th ed). Philadelphia: Elsevier Inc.

Maaijwee, N. A. M. M., Arntz, R. M., Rutten-Jacobs, L. C. A., Schaapsmeerders, P., Schoonderwaldt, H. C., Dijk, E. J. v., \& Leeuw, F. E. d. (2015). Post-stroke fatigue and its association with poor functional outcome after stroke in young adults. Journal of Neurology Neurosurgery and Psychiatry, 86(10), 1120-1126. DOI:10.1136/jnnn-2014-308784

NINDS. (2011). Post-Stroke Rehabilitation Fact Sheet. Retrieved from http://www.ninds.nih.gov/disorders/stroke/post_stroke_rehab_brochure_508comp.pdf. accessed January 15th, 2017

Onabajo, G.V. \& Adamu, A.(2014). Impact of poststroke fatigue on health-related quality of life of nigerian stroke survivors. Journal of Stroke 2014;16(3):195-201. http://dx.doi.org/10.5853/jos.2014.16.3.195

Parks, N. E., Eskes, G. A., Gubitz, G. J., Reidy, Y., Christian, C., \& Phillips, S. J. (2012). Fatigue impact scale demonstrates greater fatigue in younger stroke survivors. The Canadian Journal of Neurological Sciences. Le Journal Canadien Des Sciences Neurologiques, 39(5), 619-625. DOI:10.1017/S0317167100015353

Ponchel, A., Bombois, S., Bordet, R., \& Hénon, H. (2015). Factors associated with poststroke fatigue: A systematic review. Stroke Research and Treatment, 2015, 1-11. DOI:10.1155/2015/347920

Videbeck, S.L. (2008). Buku Ajar Keperawatan Jiwa. Jakarta: Penerbit Buku Kedokteran, EGC

Wang, S., Wang, J., Wang, P., \& Chen, R. (2014). Determinants of fatigue after first-ever ischemic stroke during acute phase: E110037. PLoS One, 9(10) DOI:10.1371/journal.pone.0110037

Wu, S., Mead, G., Macleod, M., \& Chalder, T. (2014). Model of understanding fatigue after stroke. Stroke, 46(3), 893-898. https://doi.org/10.1161/STROKEAHA.114.006647

Yager, J. (2014). Does Anxiety Actually Increase Risk for Stroke? NEJM Journal Watch.Psychiatry, (January). Retrieved from http://remotelib.ui.ac.id:2073/docview/1477160742/2EDF79FC1F114030PQ/6?accountid=17242\# 